\title{
Genetic analysis of pigmented tuber flesh in potato
}

\author{
Yongfei Zhang $\cdot$ Chun Suk Jung $\cdot$ Walter S. De Jong
}

Received: 18 November 2008 / Accepted: 23 March 2009 / Published online: 11 April 2009

(c) The Author(s) 2009. This article is published with open access at Springerlink.com

\begin{abstract}
Interest in anthocyanin-pigmented potato tuber flesh is increasing. To genetically map and characterize loci that influence this trait, diploid potato clone 10618-01, which has partially pigmented flesh, was crossed with diploid 320-02, which has white flesh. Almost all progeny exhibited purple coloration in the flesh, with some clones having only a small percentage of tissue pigmented, other clones having most tissue pigmented, and the majority of clones showing intermediate color phenotypes. The two parents and 228 progeny were genotyped with 493 AFLP, 8 CAPS, and 13 SSR markers. QTLs influencing extent of flesh pigmentation were detected on chromosomes 5, 8, and 9. The potato homolog of Petunia an1, a basic helix-loophelix (bHLH) transcriptional regulator of anthocyanin biosynthesis, was found to co-localize with the QTL on chromosome 9. A CAPS marker based on this gene was used to evaluate a collection of 21 tetraploid potato clones with highly or fully pigmented red or purple flesh, as well as 53 cultivars with white or yellow flesh. All 21 pigmentedflesh clones shared a marker allele that was present in only 21 of the 53 white and yellow clones, suggesting that a common bHLH allele contributes toward, although it is clearly not sufficient for, highly or fully pigmented tuber flesh in cultivated potato.
\end{abstract}

Communicated by C. Gebhardt.

Y. Zhang · C. S. Jung · W. S. De Jong ( $\varangle)$

Department of Plant Breeding and Genetics,

Cornell University, Ithaca, NY 14853-1901, USA

e-mail: wsd2@cornell.edu

\section{Introduction}

Consumer interest in potatoes with red or purple flesh has been increasing over the past decade, in part because of novel appearance, and in part because of the perceived benefits of higher antioxidant content (Tsuda et al. 2000; Ross and Kasum 2002; Brown et al. 2003, 2005, 2007; Scalbert et al. 2005). Red and purple tuber flesh color results from the accumulation of anthocyanin pigments (Lewis et al. 1998; Rodriguez-Saona et al. 1998; Naito et al. 1998; Eichhorn and Winterhalter 2005).

Pigmented tuber flesh is conferred by the $P f$ locus (De Jong 1987). $P f$ is tightly linked with $I$, which is required for pigmentation of tuber skin and maps to chromosome 10 (De Jong 1987; Dodds and Long 1955; van Eck et al. 1994). The $I$ locus is also known as $D$ in tetraploid potatoes (Salaman 1910). $P f$ alone is not sufficient for tuber flesh to be completely pigmented; potatoes with this gene may exhibit a small, intermediate, or large degree of flesh coloration. In many plants, tissue-specific accumulation of anthocyanins is mediated by R2R3MYB genes and/or bHLH regulators (Cone et al. 1986; Ludwig et al. 1989; Ludwig and Wessler 1990; Quattrocchio et al. 1998, 1999; Selinger et al. 1998). The potato ortholog of Petunia an2, an R2R3MYB regulator of anthocyanin production, maps to the same region of the genome as $P f$ and $I$ (De Jong et al. 2004).

Several other potato genes are also known to influence potato color. The $R$ locus, which co-segregates with dihydroflavonol 4-reductase (De Jong et al. 2003), is required for the production of red anthocyanins, while the $P$ locus, which codes for flavonoid $3^{\prime}, 5^{\prime}$-hydroxylase (Jung et al. 2005), is required for production of purple pigments.

Several recent studies have reported on potential health benefits of consuming potatoes with anthocyanin-pigmented flesh. For example, rats fed with purple potato flakes have 
Table 1 CAPS markers developed in this study

\begin{tabular}{|c|c|c|c|c|}
\hline Marker & $\begin{array}{l}\text { Approx. } \\
\text { product size (bp) }\end{array}$ & $\begin{array}{l}\text { Restriction } \\
\text { enzyme }\end{array}$ & Chromosome & Primer sequences \\
\hline $21 \mathrm{BA}$ & $470 / 400$ & None & 10 & $\begin{array}{l}\text { F: GTGATTATGTCATCCAAAAGTTTATAG } \\
\text { R: GAATTTCTGAGGTTGAGGTCTTA }\end{array}$ \\
\hline ans & 700 & HaeIII & 8 & $\begin{array}{l}\text { F: TATTGCTTGTACTTCTATTTTTCGAGATAG } \\
\text { R: CTTGGCATATTCACTTGTTGCT }\end{array}$ \\
\hline bch6 & 400 & $B c r \mathrm{I}$ & 6 & $\begin{array}{l}\text { F: AACAACCTCACATGTTTCTCCAA } \\
\text { R: CAAATGTACCCAACATTTCGGTTA }\end{array}$ \\
\hline chi & 800 & MseI & 5 & $\begin{array}{l}\text { F: ATAGAGGTTTGGAGATTGAAGG } \\
\text { R: ACTACACTTTGCTGCAGGGGA }\end{array}$ \\
\hline chs & 1600 & $A l u \mathrm{I}$ & 5 & $\begin{array}{l}\text { F: GCGACTCCTTCGAACTGTG } \\
\text { R: TGAAGTTTTTCGGGCTTTAGGC }\end{array}$ \\
\hline CT203 & 760 & $A l u \mathrm{I}$ & 10 & $\begin{array}{l}\text { F: AGTGACGATGATGACAGAGGAGAA } \\
\text { R: AAATGGACTAAAGCATATAGCCGG }\end{array}$ \\
\hline GP24 & 900 & $A l u \mathrm{I}$ & 6 & $\begin{array}{l}\text { F: CTGCAGTCAAGGGATACATTT } \\
\text { R: GCGTCTCTGCAATCTATTTCT }\end{array}$ \\
\hline jaf13 & 1480 & RsaI & 8 & $\begin{array}{l}\text { F: GAAGATCCTAACCTCATTCAGCAAATAAAA } \\
\text { R: GTTGCTTAAAATTATGGAGGCACTGA }\end{array}$ \\
\hline Stan 1 & 1600 & TaqI & 9 & $\begin{array}{l}\text { F: CGGCCCTAGTTATGATGAATTATCACA } \\
\text { R: ACCTCCACTTTAAGTTCCCTTAGC }\end{array}$ \\
\hline UGPase & 600 & $R s a \mathrm{I}$ & 11 & $\begin{array}{l}\text { F: CACCTTGACTGATGAGGGCTAT } \\
\text { R: TGGCACCAGCAGCTACTCTA }\end{array}$ \\
\hline zep & 1000 & $B f u C I$ & 2 & $\begin{array}{l}\text { F: AGAGGGATTTAAGTGCTATCAGAG } \\
\text { R: CCAGTATAACAAGTGTAGCCAGAG }\end{array}$ \\
\hline
\end{tabular}

significantly higher serum antioxidant potential and hepatic $\mathrm{Cu} / \mathrm{Zn}$-superoxide dismutase in the liver (Han et al. 2006). Potato anthocyanin may also help combat both prostate cancer (Reddivari et al. 2007) and breast cancer (Thompson et al. 2009). To more efficiently manipulate tuber flesh color in our applied breeding program, we would like to better understand the genetic basis for flesh pigmentation. Toward this end, we constructed a diploid population that segregates for degree of tuber flesh coloration, and report here on a QTL analysis of the pigmented flesh trait, as well as a follow-up marker analysis of tetraploid potato cultivars with and without pigmented tuber flesh.

\section{Materials and methods}

Plant materials

Diploid potato clone 10618-01, which has purple, partially pigmented tuber flesh, was crossed as a female with whitefleshed diploid 320-02 to form an $\mathrm{F}_{1}$ mapping population consisting of 228 clones. Both diploid parents were kindly provided by H. De Jong (AAFC, Fredericton, NB). WIS clones with pigmented tuber flesh were kindly provided by S. Janksy (USDA-ARS, Madison, WI). POR04PG01-2 was kindly provided by C. Brown (USDA-ARS, Prosser, WA). NY clones were provided by the Cornell University potato breeding program.

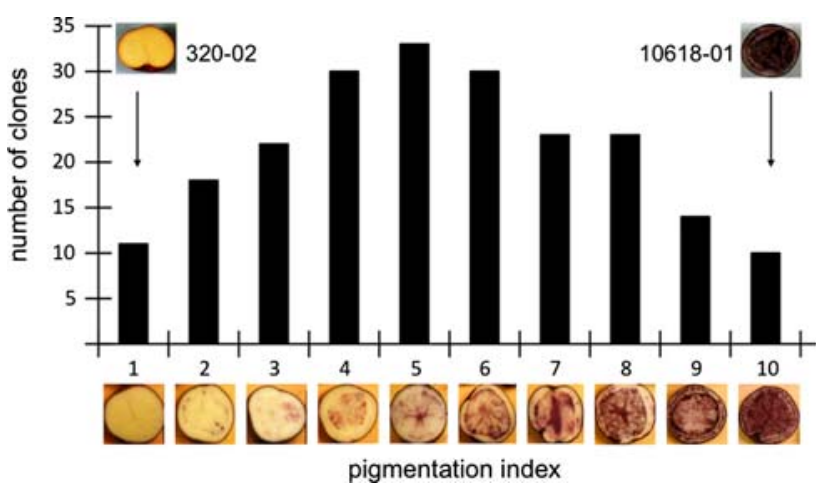

Fig. 1 Distribution of flesh color phenotypes observed in 2006 in the $F_{1}$ progeny of a cross between diploid clones 10618-01 and 320-02

Phenotyping

The extent of tuber flesh coloration was evaluated with tubers produced in the greenhouse. Each clone was grown in two pots, and the largest tuber from each pot was scored. The average score of the two tubers was used for QTL analysis. All 228 progeny, as well as both parents, were genotyped. After genotyping, two daughter clones appeared to be identical; one of the two was excluded from subsequent analysis. Thirteen of the remaining 227 clones did not tuberize well or died in 2006, and were not included in any QTL analyses. A further 15 clones did not tuberize well or 
Table 2 QTLs detected by Kruskal-Wallis (KW) and Interval Mapping (IM) using phenotype data from 2006
${ }^{\text {a }}$ Marker with highest significance score

\begin{tabular}{llllll}
\hline QTL model & \multirow{2}{*}{ Parent } & \multicolumn{2}{l}{ QTL parameters } & \\
\cline { 3 - 6 } & & Chromosome & Marker $^{\mathrm{a}}$ & Significance value & Percent variation $\left(r^{2}\right)$ \\
\hline \multirow{2}{*}{ KW } & \multirow{2}{*}{$30618-01$} & 9 & E32M48-233 & 0.0001 & N/A \\
& & 5 & E32M49-442 & 0.001 & N/A \\
& \multirow{2}{*}{$320-02$} & 8 & P14M37-134 & 0.0005 & N/A \\
& & 5 & E35M54-162 & 0.001 & N/A \\
IM & \multirow{2}{*}{$10618-01$} & 9 & E32M48-233 & LOD 3.6 & 8.1 \\
& & 5 & E32M49-442 & LOD 3.6 & 8.1 \\
& \multirow{2}{*}{$320-02$} & 8 & P14M37-134 & LOD 2.9 & 6.5 \\
& & 5 & E35M54-162 & LOD 3.7 & 8.1 \\
\hline
\end{tabular}

died in 2007, and were not used for QTL analyses that year. Flesh coloration was scored on an arbitrary 1-10 scale $(1=$ no flesh pigmentation, $10=$ almost completely pigmented), where the distribution of pigment was assessed in equatorial cross sections of mature tubers. Flesh coloration was scored in both 2006 and 2007.

\section{Marker analysis}

Genomic DNA was extracted from plants grown in the greenhouse using a Qiagen DNA kit, following the manufacturer's instructions. AFLP markers were generated with $14 \mathrm{Pst}+2 / \mathrm{Mse}+3$ and $10 \mathrm{Eco}+2 / \mathrm{Mse}+3$ AFLP primer combinations according to Vos et al. (1995), using ${ }^{33} \mathrm{P}$-labeled $P s t \mathrm{I}$ or $E c o \mathrm{R} 1$ primers. AFLP amplification products were separated on a $5 \%$ denaturing polyacrylamide gel. Sizes of amplification products were estimated by comparison to a Sequamark 10 base ladder (Research Genetics, Huntsville, $\mathrm{AL}$ ). Images were visualized by exposing film against dried acrylamide sequencing gels. Eight CAPS markers (Konieczny and Ausubel 1993) (SbeII-Chen et al. 2001; F35H-4F/4R_Jung et al. 2005; 21BA, bch6, CT203, GP24, UGPase, and zep are described in Table 1) and 13 polymorphic SSR markers of known chromosomal location (STM0003, STM1104, STM1106, STM1053, STM2020, STM2022, STM3009, STM3010, STM3016, StI011, StI014, StI041, and StI049) (Milbourne et al. 1998; Feingold et al. 2005) were used to identify chromosomes.

\section{Mapping}

Marker data were analyzed with JoinMap 3.0 (Van Ooijen and Voorrips 2001). Linkage groups were assembled using the Kosambi function (Kosambi 1943). Twenty-two linkage groups were assembled at LOD thresholds of eight or greater. Chromosomes 2 and 7 of female parent 10618-01 were assembled at LOD 6 and LOD 5, respectively. Each linkage group was labeled with at least one anchor marker of known location.
QTL analysis

QTL analysis was performed with the program MapQTL 5 (Van Ooijen 2004). Two analysis models (Kruskal-Wallis and Interval Mapping) were used. A LOD threshold of 2.85 for declaring significance $(P<0.05)$ for interval mapping was established by empirically permuting the data 1000 times. Linkage map and QTL locations were visualized using MapChart 2.1 (Voorrips 2002). QTL analysis was repeated with phenotypic data from 2006 and 2007.

Association of QTLs with anthocyanin pathway genes

CAPS markers were designed against five potato anthocyanin pathway genes (ans, Stan1, chi, chs, jafl3; Table 1). For each CAPS marker, genomic DNA was amplified using the following thermal profile: $94^{\circ} \mathrm{C}$ for $2 \mathrm{~min}$, then 35 cycles of $\left[94^{\circ} \mathrm{C}, 20 \mathrm{~s} ; 72^{\circ} \mathrm{C}, 60 \mathrm{~s} ; 56^{\circ} \mathrm{C}, 30 \mathrm{~s}\right]$. PCR products were digested with the corresponding restriction enzyme for $3 \mathrm{~h}$, then visualized on a $2 \%$ agarose gel.

\section{Results}

The progeny of a cross between diploid 10618-01, which has purple skin and partially colored (purple and white) tuber flesh, and diploid 320-02, which has red skin and white flesh, segregated extensively for extent of purple color in tuber flesh. After harvest in 2006, the flesh of 11 progeny did not appear to be pigmented at all, the flesh of 10 progeny were heavily pigmented, while the remaining 193 progeny displayed intermediate degrees of purple flesh coloration (Fig. 1). All progeny had purple tuber skin. The extent of tuber flesh coloration was scored on a 1-10 scale (Fig. 1).

To identify loci influencing extent of flesh coloration, the progeny and both parents were evaluated with 514 molecular markers including 493 AFLP, 13 SSR, and 8 CAPS markers. Analysis with JoinMap 3.0 readily separated markers into 12 maternal and 12 paternal linkage 
Fig. 2 Location of QTLs that influenced extent of tuber flesh coloration in 2006. Map locations for anthocyanin-related genes chi, chs, and Stanl are also shown

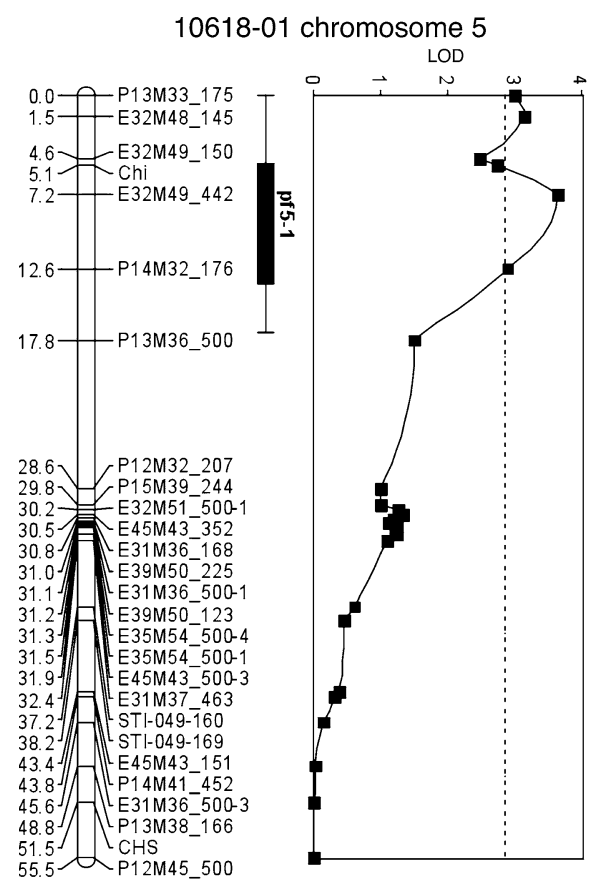

10618-01 chromosome 9
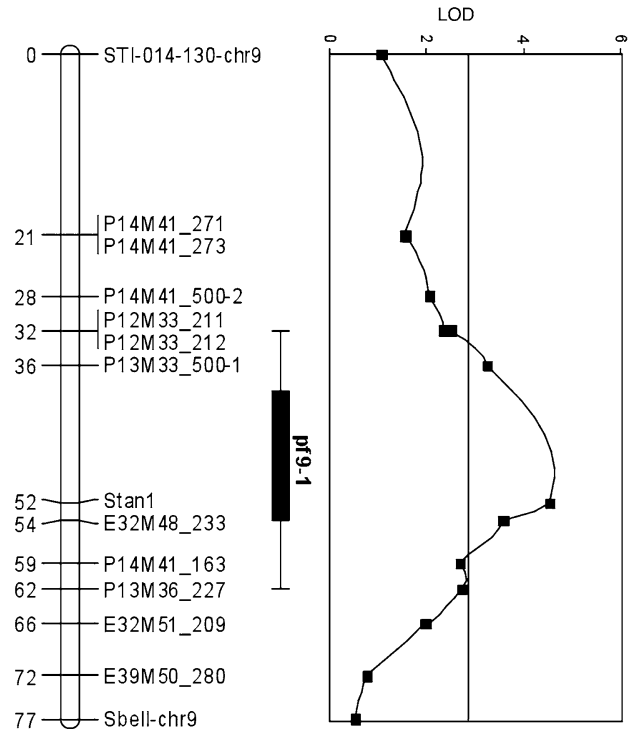

320-02 chromosome 5

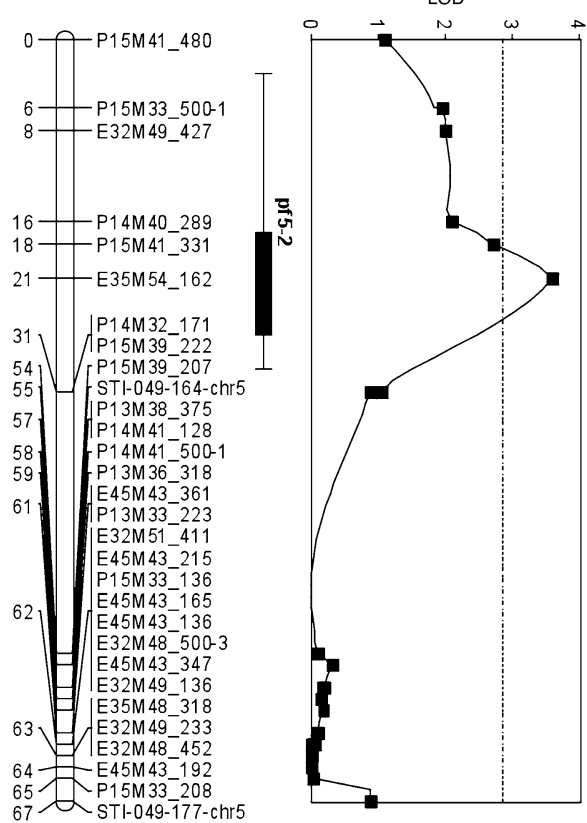

320-02 chromosome 8

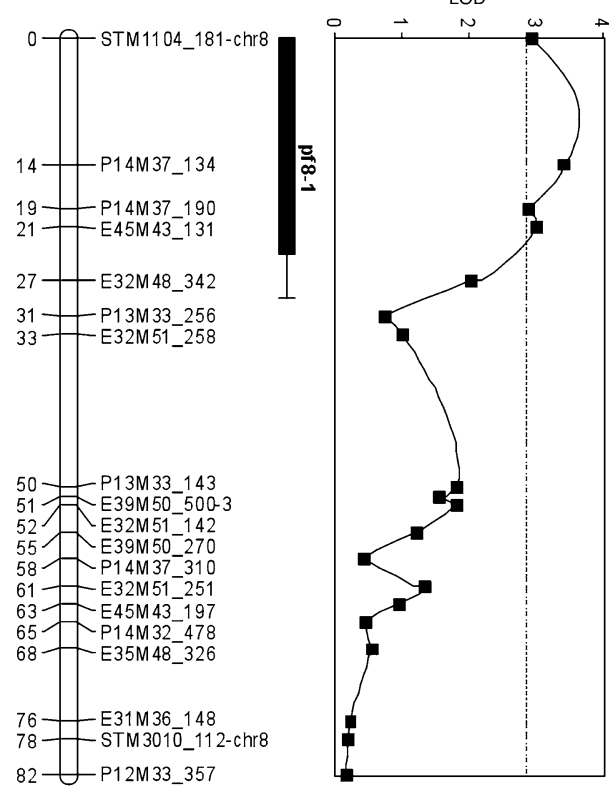

groups. A total of 496 markers could be placed in linkage groups with a LOD score of 5 or higher. The map of 10618-01 totaled $753 \mathrm{cM}$ in length and comprised 212 markers, while the map of 320-02 totaled $907 \mathrm{cM}$ in length and was made up of 284 markers. All 24 linkage groups included at least one anchor marker of known chromosomal location.

Marker and year 2006 trait data were then analyzed using both nonparametric (Kruskal-Wallis) and parametric (interval mapping) approaches. Kruskal-Wallis analysis revealed significant $(P<0.001)$ loci on chromosome 5 of both parents: for 10618-01, at AFLP marker E32M49-442, and for 320-02, at marker E53M54-162 (Table 2). In addition, highly significant loci were detected on chromosome 8 of 320-02 at marker P14M37-134 $(P<0.0005)$ and on chromosome 9 of 10618-01 at marker E32M48-233 $(P<0.0001)$ (Table 2). QTLs at comparable locations were identified by interval mapping (Fig. 2, Table 2). The same loci were detected when phenotypic data for year 2007 was analyzed separately. Tuber pigmentation scores were not 
Fig. 3 Association between colored tuber flesh and a CAPS marker allele based on the potato homolog of Petunia an1. Genomic DNA was amplified with Stan 1 primers (Table 1), restricted with $T a q$ I, and electrophoresed through a $2 \%$ agarose gel. An arrow denotes the approximately $980 \mathrm{bp}$ band present in all clones tested with red or purple tuber flesh

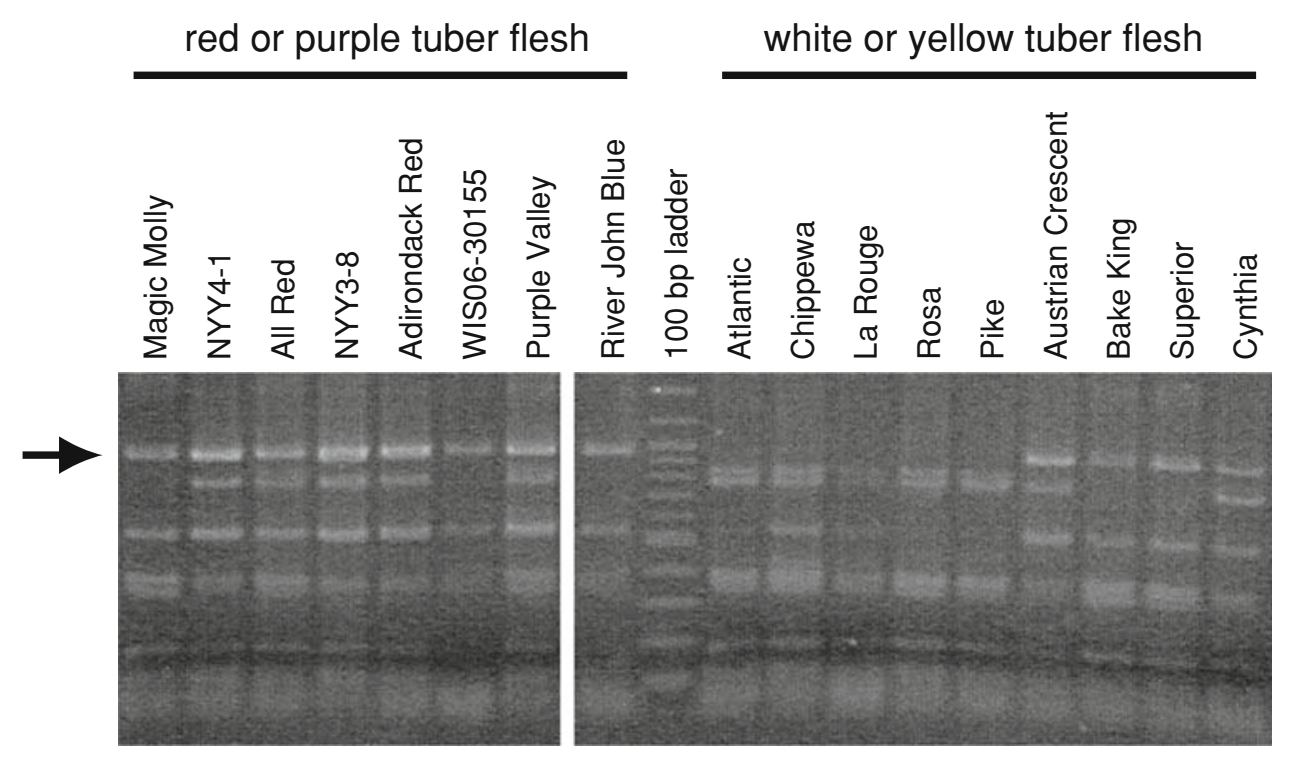

identical in 2006 and 2007, but were highly correlated $\left(r^{2}=0.61\right)$. Two additional loci were detected only in 2007 , on chromosome 8 of 10618-01 at marker E32M48-318 (LOD 3.1) and chromosome 3 of 320-02 at marker E39M50-249 (also with LOD 3.1) (data not shown).

We subsequently tested whether any known anthocyanin biosynthetic or regulatory genes co-localize with these QTLs. Potato chromosome 5 is known to code for at least two anthocyanin biosynthesis genes, chalcone isomerase (chi) and chalcone synthase (chs); chromosome 8 is known to harbor a basic helix-loop-helix (bHLH) anthocyanin regulatory gene (homolog of Petunia jaf13), as well as anthocyanidin synthase (ans); and chromosome 9 is known to code for a bHLH gene homologous to petunia anthocyanin 1 (an1) (Spelt et al. 2000; De Jong et al. 2004). CAPS markers were developed for all these genes (Table 1). Two of the five genes mapped under QTLs detected in 1061801: chi on chromosome 5 and Stan1, the potato homolog of an1, on chromosome 9 (Fig. 2). Stan 1 explained more phenotypic variation-11\%-than AFLP marker E32M48233, which explained $8.1 \%$ (Table 2). The relationship between the potato homologs of jaf13 and ans with the QTL on chromosome 8 could not be evaluated, as neither CAPS marker was polymorphic in 320-02. The fifth gene, chs, mapped far from the QTL on chromosome 5 of 1061801 (Fig. 2).

CAPS markers based on ans, chi, Stan 1, and jaf13 were tested for possible relationship with pigmented flesh in a panel of diverse potato germplasm consisting of 21 tetraploid potato clones with red or purple flesh and 53 clones with white or yellow tuber flesh. The Stan1 CAPS marker revealed a common digestion product, about $980 \mathrm{bp}$ in size, in all 21 of the clones with pigmented flesh (Fig. 3 and Table 3). This same digestion product was present in only
21 of 53 white- and yellow-fleshed clones (Fig. 3 and Table 3), suggesting that a common bHLH allele contributes toward, but is not sufficient, for the ability to accumulate anthocyanin in potato tuber flesh. No association with flesh color was observed with CAPS markers based on jaf13, ans or chi in the same panel.

\section{Discussion}

This study detected loci on three chromosomes- 5,8 , and 9 - that mediate degree of tuber flesh pigmentation. Alleles influencing this trait descended from both the white- and purple-fleshed parents, with the white-fleshed parent contributing alleles from chromosome 5 and 8 , and the purple-fleshed parent contributing alleles from chromosomes 5 and 9.

The only locus that has previously been implicated in pigmentation of tuber flesh, $P f$, is presumably located on chromosome 10, as Pf is tightly linked to I (De Jong 1987), and $I$ has been mapped to chromosome 10 (Van Eck et al. 1994). If $P f$ segregated in this cross, we would have expected half the progeny to exhibit white flesh. Instead, only 11 of 214 progeny had unpigmented flesh, suggesting that $10618-01$ is homozygous for $P f$, and that $P f$ is necessary, but not sufficient, for anthocyanin-pigmented tuber flesh. No polymorphic markers from chromosome 10 segregated aberrantly, so $P f$ must have been transmitted to either half or all progeny. As tuber skin color did not segregate in this cross-all progeny had purple-skinned tubers-the genes required for anthocyanin production per se were present in all progeny. Thus, the relatively few whitefleshed progeny must have been white for a reason other than lacking a necessary biosynthetic gene. 
Table 3 Presence/absence of $\approx 980$ bp Stanl marker allele in a panel of potato clones with and without anthocyanin-pigmented tuber flesh

\begin{tabular}{|c|c|c|}
\hline Potato clone & $\begin{array}{l}\text { Flesh } \\
\text { color }\end{array}$ & $\begin{array}{l}\text { Stan1 } 980 \mathrm{bp} \\
\text { fragment present } \\
(1=\text { yes, } 0=\text { no })\end{array}$ \\
\hline Adirondack Blue & Purple & 1 \\
\hline Adirondack Red & Red & 1 \\
\hline All Red & Red & 1 \\
\hline Huckleberry & Red & 1 \\
\hline Magic Molly & Purple & 1 \\
\hline NYH52-1 & Purple & 1 \\
\hline NYS48-6 & Purple & 1 \\
\hline NYY3-8 & Red & 1 \\
\hline NYY4-1 & Red & 1 \\
\hline POR04PG01-2 & Purple & 1 \\
\hline Purple Peruvian & Purple & 1 \\
\hline Purple Valley & Purple & 1 \\
\hline River John Blue & Purple & 1 \\
\hline WIS00-4252-1 & Purple & 1 \\
\hline WIS01-1131-1 & Purple & 1 \\
\hline WIS01-1131-5 & Red & 1 \\
\hline WIS06-3124 & Purple & 1 \\
\hline WIS06-30155 & Purple & 1 \\
\hline WIS06-30244 & Purple & 1 \\
\hline WIS06-30340 & Purple & 1 \\
\hline WIS99-2743 & Purple & 1 \\
\hline Allegany & White & 0 \\
\hline Amandine & Yellow & 1 \\
\hline Andover & White & 0 \\
\hline Atlantic & White & 0 \\
\hline Austrian Crescent & Yellow & 1 \\
\hline Bake King & White & 1 \\
\hline Bintje & Yellow & 1 \\
\hline Carola & Yellow & 0 \\
\hline Chieftain & White & 0 \\
\hline Chippewa & White & 0 \\
\hline Cynthia & Yellow & 0 \\
\hline Desiree & Yellow & 1 \\
\hline Eva & White & 0 \\
\hline German Butterball & Yellow & 1 \\
\hline Idarose & White & 1 \\
\hline Katahdin & White & 0 \\
\hline Kennebec & White & 0 \\
\hline Keuka Gold & Yellow & 1 \\
\hline La Rouge & White & 0 \\
\hline Lehigh & Yellow & 0 \\
\hline Lenape & White & 0 \\
\hline Monona & White & 0 \\
\hline Nordonna & White & 1 \\
\hline Norland & White & 1 \\
\hline NY97 & White & 1 \\
\hline
\end{tabular}

Table 3 continued

\begin{tabular}{|c|c|c|}
\hline Potato clone & $\begin{array}{l}\text { Flesh } \\
\text { color }\end{array}$ & $\begin{array}{l}\text { Stan1 } 980 \mathrm{bp} \\
\text { fragment present } \\
(1=\text { yes, } 0=\text { no })\end{array}$ \\
\hline NY99 & White & 0 \\
\hline NY115 & White & 0 \\
\hline NY118 & White & 1 \\
\hline NY120 & White & 1 \\
\hline NY121 & White & 0 \\
\hline NY123 & White & 0 \\
\hline NY127 & White & 0 \\
\hline NY128 & White & 0 \\
\hline NY129 & White & 0 \\
\hline NY130 & White & 0 \\
\hline NY132 & White & 0 \\
\hline NYT15-1 & White & 0 \\
\hline Pike & White & 0 \\
\hline Prince Hairy & White & 1 \\
\hline Reba & White & 0 \\
\hline Red La Soda & White & 0 \\
\hline Redsen & White & 1 \\
\hline Rideau & White & 1 \\
\hline Rosa & White & 0 \\
\hline Salem & White & 0 \\
\hline Sandy & Yellow & 0 \\
\hline Serrana Inta & Yellow & 1 \\
\hline Snowden & White & 0 \\
\hline Stirling & White & 1 \\
\hline Superior & White & 1 \\
\hline Sylvia & Yellow & 0 \\
\hline Yagana & Yellow & 1 \\
\hline Yukon Gold & Yellow & 1 \\
\hline
\end{tabular}

Although the genes underpinning flesh coloration QTLs were not conclusively established in this study, two promising candidates-chi (for a QTL on chromosome 5) and a bHLH transcription factor similar to Petunia anl (for a QTL on chromosome 9)-were identified. Both of these genes mapped close to, or under, the peak of the respective QTLs. It is not obvious how chi, an anthocyanin biosynthetic gene, might influence degree of flesh pigmentation; perhaps this gene exhibits functional variation in its promoter region, leading to differences in the range of tissues in which it can be expressed. That the potato homolog of Petunia anl may play a role in tissue-specific expression was not surprising, as bHLH regulators of anthocyanin biosynthesis, such as delila in Antirrhinum majus (Goodrich et al. 1992), B in Zea mays (Selinger et al. 1998), ivs in Ipomoea tricolor (Park et al. 2004), tt8 of Arabidopsis thaliana (Nesi et al. 2000; Baudry et al. 2006), the rice Purple leaf (Pl) locus (Sakamoto et al. 2001), and the rice 
red grain locus $R c$ (Sweeney et al. 2006) are all known to mediate tissue-specific expression of anthocyanins.

Further evidence that the potato homolog of Petunia an 1 (or a gene tightly linked to it) is associated with pigmented tuber flesh came from a comparison of varieties with and without pigmented flesh. All 21 pigmented flesh clones tested to date share an approximately 980 bp Stanl CAPS marker allele. Eight of the pigmented flesh clones evaluated were developed in Wisconsin (WIS clones), six were developed in New York (NY and Adirondack clones), one was developed in Alaska (Magic Molly), one was developed in Washington (POR clone), one was developed in Korea (Purple Valley), and the remaining four are of unknown origin. Though potato clones that accumulate anthocyanin in tuber flesh are not uncommon in Andean landraces, this trait has generally been selected against in modern potato breeding, just as pigmented kernels were selected against in maize (Johannessen et al. 1970) and pigmented grains were selected against in rice (Sweeney et al. 2007). Nevertheless, as understanding of the potential health benefits conferred by anthocyanins has increased over the past decade, interest in consuming anthocyanin-rich plant tissues has also increased dramatically. Markers based on Stanl may thus prove useful for those seeking to more efficiently manipulate the nutritionally important trait of pigmented tuber flesh in applied potato breeding programs.

Acknowledgments We thank Shuping Cheng for helping with SSR data collection, and the field crew of the Cornell potato breeding program for maintaining the diploid population.

Open Access This article is distributed under the terms of the Creative Commons Attribution Noncommercial License which permits any noncommercial use, distribution, and reproduction in any medium, provided the original author(s) and source are credited.

\section{References}

Baudry A, Caboche M, Lepiniec L (2006) TT8 controls its own expression in a feedback regulation involving TTG1 and homologous MYB and bHLH factors, allowing a strong and cell-specific accumulation of flavonoids in Arabidopsis thaliana. Plant J 46:768-779

Brown CR, Wrolstad R, Durst R, Yang CP, Clevidence B (2003) Breeding studies in potatoes containing high concentrations of anthocyanins. Am J Potato Res 80:241-250

Brown CR, Culley D, Yang CP, Durst R, Wrolstad R (2005) Variation of anthocyanin and carotenoid contents and associated antioxidant values in potato breeding lines. J Am Soc Hort Sci 130:174-180

Brown CR, Culley D, Bonierbale M, Amoros W (2007) Anthocyanin, carotenoid content, and antioxidant values in Native South American Potato Cultivars. Hortscience 42:1733-1736

Chen X, Salamini F, Gebhardt C (2001) A potato molecular-function map for carbohydrate metabolism and transport. Theor Appl Genet 102:284-295

Cone KC, Burr FA, Burr B (1986) Molecular analysis of the maize anthocyanin regulatory locus $\mathrm{C} 1$. Proc Natl Acad Sci USA 83:9631-9635
De Jong H (1987) Inheritance of pigmented tuber flesh in cultivated diploid potatoes. Am Potato J 64:337-343

De Jong WS, De Jong DM, De Jong H, Kalazich J, Bodis M (2003) An allele of dihydroflavonol 4-reductase associated with the ability to produce red anthocyanin pigments in potato (Solanum tuberosum L.). Theor Appl Genet 107:1375-1383

De Jong WS, Eannetta NT, De Jong DM, Bodis M (2004) Candidate gene analysis of anthocyanin pigmentation loci in the Solanaceae. Theor Appl Genet 108:423-432

Dodds KS, Long DH (1955) The inheritance of colour in diploid potatoes: types of anthocyanidins and their genetic loci. J Genet 53:136-149

Eichhorn S, Winterhalter P (2005) Anthocyanins from pigmented potato (Solanum tuberosum L.) varieties. Food Res Int 38:943-948

Feingold S, Lloyd J, Norero N, Bonierbale M, Lorenzen J (2005) Mapping and characterization of new EST-derived microsatellites for potato (Solanum tuberosum L.). Theor Appl Genet 111:456-466

Goodrich J, Carpenter R, Coen ES (1992) A common gene regulates pigmentation pattern in diverse plant species. Cell 68:955-964

Han KH, Sekikawa M, Shimada K, Hashimoto M, Hashimoto N, Noda T, Tanaka H, Fukushima M (2006) Anthocyanin-rich purple potato flake extract has antioxidant capacity and improves antioxidant potential in rats. Br J Nutr 96:1125-1133

Johannessen CL, Wilson MR, Davenport WA (1970) The domestication of maize: process or event? Geogr Rev 60:393-413

Jung CS, Griffiths HM, De Jong DM, Cheng S, Bodis M, De Jong WS (2005) The potato $\mathrm{P}$ locus codes for flavonoid 3', 5'-hydroxylase. Theor Appl Genet 110:269-275

Konieczny A, Ausubel FM (1993) A procedure for mapping Arabidopsis mutations using co-dominant ecotype-specific PCR-based markers. Plant J 4:403-410

Kosambi DD (1943) The estimation of map distances from recombination values. Ann Eugen 12:172-175

Lewis CE, Walker JRL, Lancaster JE, Sutton KH (1998) Determination of anthocyanins, flavonoids and phenolic acids in potatoes. I: coloured cultivars of Solanum tuberosum L. J Sci Food Agric 77:45-57

Ludwig SR, Wessler SR (1990) Maize R gene family: tissue-specific helix-loop-helix proteins. Cell 62:849-851

Ludwig SR, Habera LF, Dellaporta SL, Wessler SR (1989) Lc, a member of the maize $\mathrm{R}$ gene family responsible for tissue-specific anthocyanin production, encodes a protein similar to transcriptional activators and contains the myc-homology region. Proc Natl Acad Sci USA 86:7092-7096

Milbourne D, Meyer RC, Collins AJ, Ramsay LD, Gebhardt C, Waugh $\mathrm{R}$ (1998) Isolation, characterisation and mapping of simple sequence repeat loci in potato. Mol Gen Genet 259:233-245

Naito K, Umemura Y, Mori M, Sumida T, Okada T, Takamatsu N, Okawa Y, Hayashi K, Saito N, Honda T (1998) Acylated pelargonidin glycosides from a red potato. Phytochemistry 47:109-112

Nesi N, Debeaujon I, Jond C, Pelletier G, Caboche M, Lepiniec L (2000) The TT8 gene encodes a basic helix-loop-helix domain protein required for expression of DFR and BAN genes in Arabidopsis siliques. Plant Cell 12:1863-1878

Park KI, Choi JD, Hoshino A, Morita Y, Iida S (2004) An intragenic tandem duplication in a transcriptional regulatory gene for anthocyanin biosynthesis confers pale-colored flowers and seeds with fine spots in Ipomoea tricolor. Plant J 38:840-849

Quattrocchio F, Wing JF, van der Woude K, Mol JN, Koes R (1998) Analysis of bHLH and MYB domain proteins: species-specific regulatory differences are caused by divergent evolution of target anthocyanin genes. Plant J 13:475-488

Quattrocchio F, Wing J, van der Woude K, Souer E, de Vetten N, Mol J, Koes R (1999) Molecular analysis of the anthocyanin2 gene of petunia and its role in the evolution of flower color. Plant Cell 11:1144-1433 
Reddivari L, Vanamala J, Chintharlapalli S, Safe SH, Miller JC (2007) Anthocyanin fraction from potato extracts is cytotoxic to prostate cancer cells through activation of caspase-dependent and caspaseindependent pathways. Carcinogenesis 28:2227-2235

Rodriguez-Saona LE, Giusti MM, Wrolstad RE (1998) Anthocyanin pigment composition of red-fleshed potatoes. J Food Sci 63:458 465

Ross JA, Kasum CM (2002) Dietary flavonoids: bioavailability, metabolic effects, and safety. Annu Rev Nutr 22:19-34

Sakamoto W, Ohmori T, Kageyama K, Miyazaki C, Saito A, Murata M, Noda K, Maekawa M (2001) The Purple leaf (Pl) locus of rice: the $\mathrm{Pl}(\mathrm{w})$ allele has a complex organization and includes two genes encoding basic helix-loop-helix proteins involved in anthocyanin biosynthesis. Plant Cell Physiol 42:982-991

Salaman RN (1910) The inheritance of colour and other characters in the potato. J Genet 1:7-46

Scalbert A, Johnson IT, Saltmarsh M (2005) Polyphenols: antioxidants and beyond. Am J Clin Nutr 81(Suppl 1):215S-217S

Selinger DA, Lisch D, Chandler VL (1998) The maize regulatory gene B-Peru contains a DNA rearrangement that specifies tissuespecific expression through both positive and negative promoter elements. Genetics 149:1125-1138

Spelt C, Quattrocchio F, Mol JN, Koes R (2000) Anthocyanin1 of petunia encodes a basic helix-loop-helix protein that directly activates transcription of structural anthocyanin genes. Plant Cell 12:1619-1632

Sweeney MT, Thomson MJ, Pfeil BE, McCouch S (2006) Caught redhanded: Rc encodes a basic helix-loop-helix protein conditioning red pericarp in rice. Plant Cell 18:283-294
Sweeney MT, Thomson MJ, Cho YG, Park YJ, Williamson SH, Bustamante CD, McCouch SR (2007) Global dissemination of a single mutation conferring white pericarp in rice. PLoS Genet 3(8): 133

Thompson MD, Thompson HJ, McGinley JN, Neil ES, Rush DK, Holm DG, Stushnoff C (2009) Functional food characteristics of potato cultivars (Solanum tuberosum L.): phytochemical composition and inhibition of 1-methyl-1-nitrosourea induced breast cancer in rats. J Food Compos Anal, in press

Tsuda T, Horio F, Osawa T (2000) The role of anthocyanins as an antioxidant under oxidative stress in rats. Biofactors 13:133-139

Van Eck HJ, Jacobs JME, Van Den Berg PMMM, Stiekema WJ, Jacobsen E (1994) The inheritance of anthocyanin pigmentation in potato (Solanum tuberosum L.) and mapping of tuber skin colour loci using RFLPs. Heredity 73:410-421

Van Ooijen JW (2004) MapQTL @ 5, software for the zapping of quantitative trait loci in experimental populations. Kyazma BV, Wageningen, the Netherlands

Van Ooijen JW, Voorrips RE (2001) JoinMap® 3.0, software for the calculation of genetic linkage maps. Plant Research International. Wageningen, the Netherlands

Voorrips RE (2002) MapChart: software for the graphical presentation of linkage maps and QTLs. J Hered 93:77-78

Vos P, Hogers R, Bleeker M, Reijans M, van de Lee T, Hornes M, Frijters A, Pot J, Peleman J, Kuiper M (1995) AFLP: a new technique for DNA fingerprinting. Nucleic Acids Res 21:4407-4414 